Jurnal Pendidikan Fisika
https://journal.unismuh.ac.id/index.php/jpf
DOI: 10.26618/jpf.v9i1.4763

\title{
Five-Tier Diagnostic Test Instrument for Uniform Circular Motion Concepts: Development, Validity, Reliability and Limited Trials
}

\author{
Nisrina Nur Ramadhani, Frida Ulfah Ermawati* \\ Physics Department, Faculty of Mathematics and Natural Science, Universitas Negeri Surabaya, \\ Surabaya, 60231, Indonesia. \\ *Corresponding author: frida.ermawati@unesa.ac.id
}

Received: December 03, 2020; Accepted: January 23, 2021; Published: January 30, 2021

\begin{abstract}
Students' understanding on Physics concepts could be different from each other. Based on the conceptual diagnostic test, especially in five-tier format, the students' different understanding can be categorized into several conception levels. One of them is misconception. For example, students consider that all objects moving on a circular trajectory called uniform circular motion (UCM). According to the Physics concept, an object in UCM must meet three criteria: an object travels along a circular path, the radius of the path is always fixed, and the object moves at a constant speed. However, a standardized conceptual diagnostic test instrument in five-tier format is not yet available. This work aims to develop a five-tier diagnostic test instrument for UCM concepts, perform validity and reliability test and use the developed instrument to identify a number of students' conception level. The research \& development method was employed to produce 15 valid and reliable questions. The validity test consisted of internal and external (content and construct empirical) aspects. The internal validity obtained was $88 \%$ (very valid). The content aspect, i.e. the false positive $=4.95 \%$ and the false negative $=5.59 \%$ both met the criteria $<10 \%$. The construct aspect obtained by a Pearson product moment correlation was $\left(r_{x y}\right)=$ $0.998>r_{\text {theoritic }}=0.355(5 \%$ sig. level $)$. The reliability level of the Alpha Cronbach coefficient $\left(r_{11}\right)=0.887$ shows that the developed instrument was valid and reliable. The limited trial result shows that the students' conception levels on the UCM concepts was generally lack of knowledge.
\end{abstract}

Keywords: conception level, five-tier diagnostic test, reliability, uniform circular motion, validity

() 2021 Physics Education Department, Universitas Muhammadiyah Makassar, Indonesia.

\section{INTRODUCTION}

Physics is a set of knowledge, way of thinking, and investigation in the form of facts, concepts, principles, theories and models (Astuti, 2015; Fitriani et al., 2017; Ilyas et al., 2020). Based on the 2013 Curriculum framework, Physics learning aims to enable students to master concepts, principles, and skills as provisions for continuing education to a higher level (Kemendikbud, 2014). However, this goal cannot be achieved easily considering that students tend to have a variety of understandings on Physics concepts 
(Pebriyanti et al., 2017). When viewed using a five-tier diagnostic test, (Anam et al., 2015) called the various understanding on Physics concepts as conception levels. Table 1

Table 1. Students' conception levels (Anam et al., 2015)

\begin{tabular}{|c|c|c|}
\hline No & Conception levels & Description \\
\hline 1 & $\begin{array}{l}\text { SC } \\
\text { (Scientific } \\
\text { Conception) }\end{array}$ & $\begin{array}{l}\text { When students answer on the first-tier and the chosen } \\
\text { reason on the third-tier are correct. The student is sure with } \\
\text { the chosen answers and reasons, and the pictures or } \\
\text { conclusions made on the fifth-tier is in accordance with the } \\
\text { Physics concept. }\end{array}$ \\
\hline 2 & $\begin{array}{l}\text { ASC } \\
\text { (Almost Scientific } \\
\text { Conception) }\end{array}$ & $\begin{array}{l}\text { When students answer on the first-tier and the chosen } \\
\text { reason on the third-tier are correct. The student is sure with } \\
\text { the chosen answers and reasons, but the pictures or } \\
\text { conclusions made on the fifth-tier is not completely in } \\
\text { accordance with the Physics concept. }\end{array}$ \\
\hline 3 & $\begin{array}{l}\text { LK } \\
\text { (Lack of } \\
\text { Knowledge) }\end{array}$ & $\begin{array}{l}\text { When only one of the students answers on the first-tier and } \\
\text { the chosen reason on the third-tier is correct. The student } \\
\text { can be sure or not with the chosen answers and reasons, and } \\
\text { the pictures or conclusions made on the fifth-tier is } \\
\text { sufficiently in accordance with the Physics concept. }\end{array}$ \\
\hline 4 & $\begin{array}{l}\text { MSC } \\
\text { (Misconception) }\end{array}$ & $\begin{array}{l}\text { When students answer on the first-tier and the chosen } \\
\text { reason on the third-tier are wrong. The student is sure with } \\
\text { the chosen answers and reasons, but the pictures or } \\
\text { conclusions made on the fifth-tier is not in accordance with } \\
\text { the Physics concept. }\end{array}$ \\
\hline 5 & $\begin{array}{l}\text { NU } \\
\text { (No Understanding } \\
\text { on Concept) }\end{array}$ & $\begin{array}{l}\text { When students answer on the first-tier and the chosen } \\
\text { reason on the third-tier are wrong. The student is not sure } \\
\text { with the chosen answers and reasons, and the pictures or } \\
\text { conclusions made on the fifth-tier is not in accordance with } \\
\text { the Physics concept. }\end{array}$ \\
\hline
\end{tabular}

Based on Table 1, misconception becomes one of the levels of conception. Misconceptions in physics learning often occur (Respatiningrum et al., 2015; Haryono et al., 2020). According to Alhinduan et al (2016); Sholihat et al., (2017); Farihah and Wildani (2018) and Rukmana (2020), misconception occurs due to a mismatch between students' understanding and scientific concepts according to experts in certain fields. Based on the first author's experience when carrying out a Pengenalan summarizes the conception levels proposed by Anam et al., (2015). 
radius $r$ at a constant speed of $v$, the particle is said to be in uniform circular motion". This means that a particle or object is said to be in UCM when it meets three criteria, namely: 1) the particle or object moves on a circular path, 2) the distance between the particle or object to the center of the circle $(r)$ is always fixed and 3) the particle moving at a constant speed. Referring to the Physics concept in the Halliday's textbook above, it can be understood that the mentioned students experienced misconceptions.

The case on students' misconceptions on UCM was also reported by Yolenta et al. (2014) and Annisa et al. (2019), each using three-tier and four-tier diagnostic tests to identify students' conception level. According to Yolenta et al. (2014), there are $39.22 \%$ of the students experienced misconceptions. Meanwhile, according to Annisa et al. (2019), $30.69 \%$ of the students experienced misconceptions on the UCM concepts; $54.48 \%$ did not understand the concepts; $8.62 \%$ understood the concept and the rest was un-code, which means that the students' answers cannot be concluded because it was not complete.

For the scheme of three-tier and also four-tier diagnostic tests, students are only given the opportunity to choose one of several answer options so there might be a possibility that the students are only guess when choosing the answer (Milenković, 2016). When the guessed answer is correct, the conclusions about the students' conception level drawn by the examiner could be inaccurate (Ermawati et al., 2019). Therefore, it will be beneficial to add a fifth-tier question (an open question) on a four-tier diagnostic test. The aim of the fifth-open question is to add the examiner's level of confidence in justifying the students' conception levels; and the developed diagnostic test with an extra fifth question in it is called a five-tier diagnostic test as reported by Bayuni et al. (2018) on changes of matters concepts and by Anam et al. (2019) on heat transfer concepts. The fifth-tier of an open question can be an instruction for students to draw a picture/concept map or to write up a conclusion based on the concepts asked in the first- and third-tier.

Recently, the work to develop a five-tier diagnostic test instrument has been reported by Qonita \& Ermawati (2020) on vector concepts, Fajriyyah \& Ermawati (2020) on kinetic theory of gases concepts, also by Salsabila \& Ermawati (2020) on elasticity concepts. However, a standardized five-tier diagnostic test instrument is not yet available up to now, including for UCM concepts.

Gurel et al. (2015), Amin et al. (2016) and Anam et al. (2019) provided guidelines for assessing students's conception levels when using five-tier diagnostic test. Table 2 provides students' conceptual levels in a fivetier diagnostic test adapted from them. Table 3 shows the description and scores of the answers for fifth-tier question in Table 2 . 
Table 2. Students' conceptual levels in a fivetier diagnostic test (Gurel et al., 2015, Amin et al., 2016 and Anam et al., 2019).

\begin{tabular}{|c|c|c|c|c|c|c|c|c|}
\hline$\ddot{z}$ & 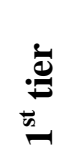 & 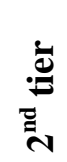 & 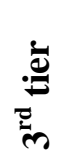 & 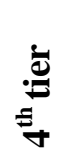 & 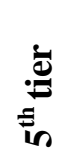 & 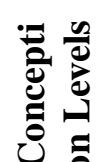 & $\begin{array}{l}\mathrm{UD} / \mathrm{UC} \\
\mathrm{ND} / \mathrm{NC} \\
\mathrm{UnC}\end{array}$ & $\begin{array}{l}=\text { Undefined Drawing/Conclusion } \\
=\text { No Drawing } / \text { Conclusion } \\
=\text { Un-Code }\end{array}$ \\
\hline
\end{tabular}

$\mathrm{SD} / \mathrm{SC}=$ Scientific Drawing/Conclusion

$\mathrm{PD} / \mathrm{PC}=$ Partial Drawing $/$ Conclusion

$\mathrm{MD} / \mathrm{MC}=$ Misconception

$\mathrm{DD} / \mathrm{MC}=$ Drawing/Conclusion

Table 3. Descriptions and scores for the fifth$(\mathrm{PD} / \mathrm{PC}) \quad \mathrm{ASC}$

(MD/MC)

(UD/UC)

$(\mathrm{ND} / \mathrm{NC})$

LK

tier answers in Table 2 (Dikmenli, 2010; Köse, 2008)

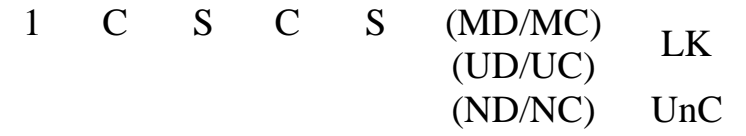

$\begin{array}{lllll}2 & \mathrm{C} & \mathrm{S} & \mathrm{C} & \mathrm{NS}\end{array}$

3 C NS C

$4 \quad \mathrm{C} \quad \mathrm{NS} \quad \mathrm{C} \quad \mathrm{NS}$

$\begin{array}{lllll}5 & \mathrm{C} & \mathrm{S} & \mathrm{W} & \mathrm{NS}\end{array}$

(PD/PC)

$\begin{array}{lllll}6 & \mathrm{C} & \mathrm{S} & \mathrm{W} & \mathrm{S}\end{array}$

or

UnC

\begin{tabular}{cl}
$\gtrless$ & Category \\
\hline & \\
1 & $\begin{array}{l}\text { Scientific } \\
\text { Drawing / } \\
\text { Conclusion } \\
\text { (SD/SC) }\end{array}$
\end{tabular}

Description

Score

When students provide a

$7 \quad \mathrm{C} \quad \mathrm{NS} \quad \mathrm{W} \quad \mathrm{S} \quad(\mathrm{MD} / \mathrm{MC})$

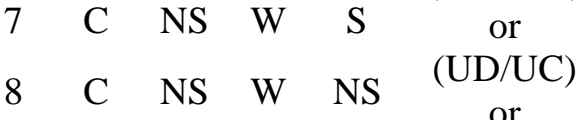

LK

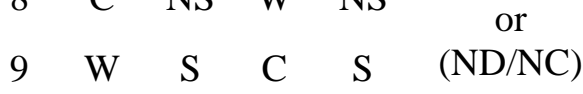

10 W $\quad$ S $\quad$ C $\quad$ NS

11 W NS C

12 W NS C NS

$13 \mathrm{~W} \quad \mathrm{~S} \quad \mathrm{~W} \quad \mathrm{NS} \quad(\mathrm{PD} / \mathrm{PC})$

or

14 W NS W S

(MD/MC)

or
(UD/UC)

NU

15 W NS W NS

or

(ND/NC)

(MD/MC)

or

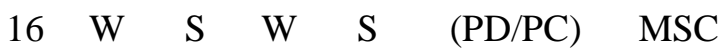

or

(UD/UC)

picture or a

comprehensive

conclusion that

100

with the Physics

concept.

When students

provide a

picture or

Partial conclusion that

2 Drawing / almost close to

Conclusion the Physics

70-99

(PD/PC) concept with

minor

deficiencies in

it.

When students

Misconcept provide a

ion picture or

3 Drawing / conclusion that

Conclusion is different with

40-69

(MD/MC) the Physics

concept.

Undefined When students

Drawing / provide a

Conclusion picture or

(UD/UC) conclusion that

does not match

with Physics

$1-39$

When there is a "tier" that is not

17 answered by students or they UnC answered more than one option concept and it cannot be understood.

\section{Note:}

No When student

$\mathrm{C}=$ Correct $\mathrm{W}=$ Wrong

$\mathrm{S}=$ Sure NS = Not Sure

5

Drawing / cannot provide

Conclusion drawing or 
Based on the introduction above, this paper is intended to develop a five-tier diagnostic test (FTDT) instrument for uniform circular motion (UCM) concepts. The FTDT instrument was written following a research \& development (R\&D) method. The validity and reliability tests were performed and the valid and reliable instrument was tested to a number of high school students to obtain their conception levels data in UCM.

\section{METHOD}

As mentioned, this work adopted the research and development $(\mathrm{R} \& \mathrm{D})$ method to develop a five-tier diagnostic test (FTDT) on uniform circular motion (UCM) concepts, examined the validity and reliability, and used the valid and reliable instrument to test the conception levels of a number of students. The following paragraphs explain the works carried out on each (R\&D) stage.

\section{A. Research stage}

What is meant by the research stage here is that the author did literature studies on the UCM concepts from some Physics textbooks, i.e. "College Physics, $9^{\text {th }}$ Edition" (2010) by Serway, "Fundamentals of Physics, $10^{\text {th }}$ Edition (2013) by Halliday and "Physics: Principles with Applications, $7^{\text {th }}$ Edition" (2014) by Giancoli to develop a draft of diagnostic test instrument. The authors takes three sub-concepts in UCM which will be written in a draft of diagnostic test, i.e. (a)
Angular Displacement, (b) Effect of Object's Mass on Linear Velocity and (c) Period. In this stage, the author also recapitulated students' potential misconceptions on UCM concepts, both obtained from the literature studies and from interview to some high school students who had already taught the UCM concepts in the previous semester. Table 4 recapitulates the three sub-concepts in UCM and the intended potential misconceptions.

Table 4. Some of Students' Potential Misconceptions in the UCM concepts

\begin{tabular}{|c|c|c|c|}
\hline$\stackrel{0}{Z}$ & 竞 & $\begin{array}{l}\text { Correct } \\
\text { Concept }\end{array}$ & $\begin{array}{c}\text { Potential } \\
\text { Misconcepti } \\
\text { on }\end{array}$ \\
\hline 1 & $\begin{array}{l}\text { Angular } \\
\text { Displace } \\
\text { ment } \\
(\theta)\end{array}$ & $\begin{array}{l}\text { An } \\
\text { International } \\
\text { Unit for } \\
\text { angular } \\
\text { displacement } \\
\text { in UCM } \\
\text { concepts is } \\
\text { radians (rad), } \\
\text { so if the value } \\
\text { is still } \\
\text { expressed in } \\
\text { degree }\left(^{\circ}\right) \text { unit, } \\
\text { then it must be } \\
\text { converted into } \\
\text { radians (rad) } \\
\text { first (Serway, } \\
\text { 2010: 200). }\end{array}$ & $\begin{array}{l}\text { Students } \\
\text { assumed that } \\
\text { the } \\
\text { International } \\
\text { Unit for } \\
\text { angular } \\
\text { displacement } \\
\text { is degrees }\left(^{\circ}\right) \\
\text { because an } \\
\text { object is said } \\
\text { to have } \\
\text { travelled one } \\
\text { full circle if } \\
\text { it has a } 360^{\circ} \text {. }\end{array}$ \\
\hline 2 & $\begin{array}{l}\text { Effect of } \\
\text { object's } \\
\text { mass } \\
(m) \text { on } \\
\text { linear } \\
\text { velocity } \\
(v)\end{array}$ & $\begin{array}{l}\text { In UCM } \\
\text { concepts, the } \\
\text { value of linear } \\
\text { velocity }(v) \text { is } \\
\text { expressed in } \\
\text { Eq.(1): } \\
v=\frac{2 \pi r}{T} \\
\text { Based on Eq. }\end{array}$ & $\begin{array}{l}\text { Students } \\
\text { assumed that } \\
\text { object's mass } \\
(m) \text { affects } \\
\text { linear } \\
\text { velocity }(v) \\
\text { because the } \\
\text { greater mass } \\
\text { of the object, } \\
\text { then the }\end{array}$ \\
\hline
\end{tabular}




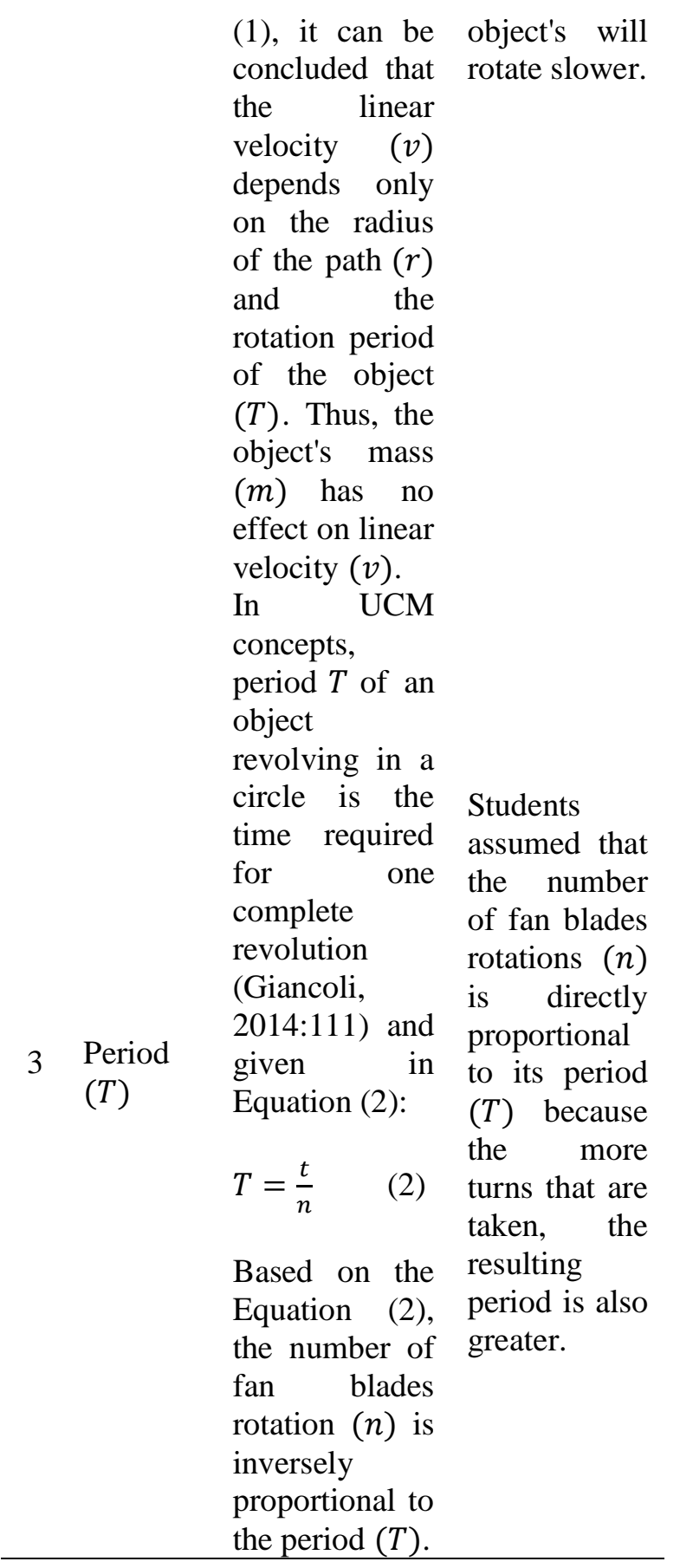

\section{B. Development stage}

\section{Instrument development}

The development stage was started by writing up a Draft-1 of the diagnostic test instrument, revised it etc. up to the Final Draft was valid and reliable. The Draft- 1 was in the form of three-tier diagnostic test that comprises of 15 questions covering the three sub-concepts in Table 4. The first-tier of the Draft-1 was multiple choice questions. The second-tier was the level of students' confidence to answer the first-tier question. The third-tier was an open-ended question in responding the first-tier question. The Draft-1 was tested to 25 public-high-school students in several districts in East Java. The aim was to select various possible reasons written by students when he/she answered the first-tier questions.

The selected answer's reasons above were then written in Draft-2 (also comprises of 15 questions). The Draft-2 was already a FTDT. The first two tier questions in the Draft-2 were the same as in the Draft-1. However, the third-tier in Draft-2 was a closed-ended question, i.e. the student's reasons when answering the questions on the first-tier. The fourth-tier in the Draft- 2 was the level of student's confidence in choosing the correct reasons. The fifth-tier was an open-ended question to confirm the level conception of students.

The Draft-2 was then tested for internal validity by two appointed UNESA's Physics lecturers. The internal validity test result was used to develop Draft-3 (15 questions), also an FTDT. The Draft-3 were tested for external validity and reliability. The validated and reliable FTDT will be the final FTDT instrument. This final instrument was ready 
for use to a number of students to access their conception levels data in the UCM.

\section{Validity and reliability test}

As mentioned, the internal validity test was conducted on the Draft-2. The internal validity contains three aspects, i.e. the aspects of content, construct and language. The evaluation indicators on the content aspect include: a) suitability between the questions and the UCM concepts, b) suitability between the questions and the question indicators, c) the suitability between the questions and the order of the sub-concepts and d) clear statements for the questions, the answers and the reasons for choosing the answers.

The construct aspect has the following evaluation indicators: a) the diagnostic test instructions are clearly stated, b) the suitability of the questions with Bloom's Taxonomy and Basic Competencies, c) the questions can identify students' conceptions, d) the choice of reasons presented can identify the causes of misconceptions that come from oneself students, e) the distractor options for reasons should be rational and homogeneous with the first-tier answers, and f) the tables, graphs and pictures presented should match the given problem.

The evaluation indicators in the language aspect consist of: a) the question must be written based on the Indonesian language rules, b) the question sentences do not cause multiple interpretations and c) the question sentences are stated clearly and communicatively.

Equation (3) was occupied to calculate \% of the internal validity (Arikunto, 2016), while Table 5 provides score ranges and interpretation of the internal validation results calculated using the Eq. (3) and Table 8 shows the internal validity results.

$$
\% P=\frac{S_{R}}{N \cdot P_{A} \cdot R} \cdot 100 \%
$$

where $\% P$ is $\%$ of internal validity, $S_{R}$ is the total score given by the validator, $N$ is the maximum score for the indicator, $P_{A}$ is the number of indicators for each validity aspect and $R$ is the number of validator (2).

Table 5. Score ranges and interpretation of the internal validation results (Riduwan and Akdon, 2013)

\begin{tabular}{cc}
\hline $\begin{array}{c}\text { Score ranges of } \\
\text { internal validation }(\%)\end{array}$ & Interpretation \\
\hline $0-20$ & Invalid \\
$21-40$ & Less valid \\
$41-60$ & Quite valid \\
$61-80$ & Valid \\
$81-100$ & Very valid \\
\hline
\end{tabular}

The external validity and reliability test was carried out on 31 high school students from several schools in Sidoarjo, Gresik and Surabaya. The intended students had learnt the UCM concepts at the previous semester. The external validity consists of content and construct aspects. The content aspect was determined based on $\%$ false positive $(F P)$ and $\%$ false negative $(F N)$ and these were calculated using Eq. (4) and (5) (Jannah \& Ermawati, 2020). $F P$ is the answer 
combination of correct-sure-wrong-surewrong (i.e. the option No. 6 in Table 2). While $F N$ is the answer combination of wrong-sure-correct-sure-wrong (i.e. No. 9 in Table 2).

$\% F P=\frac{\Sigma F P}{\sum_{\text {butir soal }} \times \Sigma_{\text {siswa }}} \times 100 \%$

$\% F N=\frac{\sum F N}{\sum_{\text {butir soal }} \times \sum_{\text {siswa }}} \times 100 \%$

Where $\Sigma F P$ is the sum of $F P, \Sigma F N$ is the sum of $F N, \Sigma_{\text {items }}$ is the number of questions (15 questions) and $\Sigma_{\text {students }}$ is the number of students who involved in the external validity and reliability test (31 students). According to Kirbulut and Geban (2014), the content aspect is valid when \% FP and $F N$ each $<10 \%$. Table 9 provides the $F P$ and $F N$ results. The construct aspect for each question and for all the 15 questions as a whole was determined based on the correlation coefficient $\left(r_{x y}\right)$ of Pearson Product Moment in Equation (6) (Arikunto, 2016).

$$
r_{x y}=\frac{\sum x y}{\sqrt{\left(\sum x^{2}\right)\left(\sum y^{2}\right)}}
$$

where $r_{x y}$ is the correlation between the $x$ and $y, x$ is the difference between the number of correct answer scores for each question in the first- and third-tier with the average score of the correct answers for all the questions; $y$ is the difference between the total score for sure answers in the second- and fourth-tier questions with the average score correct answers for all questions. Table 10 provides the result of the construct aspect for each question. An instrument is valid when the value of $r_{x y}>r_{\text {theoritic. In this work, the }}$ chosen $r_{\text {theoritic }}$ value was 0.355 with a $5 \%$ significance level considering that the number of students was 31 . Figure 1 provides a screenshot for the Product Moment $r$ value ( $\left.r_{\text {theoritic }}\right)$ for the $\mathrm{N}$ is between 27 and 33 and the sig. value is 5 and $1 \%$.

\begin{tabular}{|l|l|l|}
\hline \multirow{2}{*}{$N$} & \multicolumn{2}{|c|}{ Significance } \\
\cline { 2 - 3 } & $5 \%$ & $1 \%$ \\
\hline 27 & 0,381 & 0,487 \\
\hline 28 & 0,374 & 0,478 \\
\hline 29 & 0,367 & 0,470 \\
\hline 30 & 0,361 & 0,463 \\
\hline 31 & 0,355 & 0,456 \\
\hline 32 & 0,349 & 0,449 \\
\hline 33 & 0,344 & 0,442 \\
\hline
\end{tabular}

Figure 1. Screenshot of the value of $r$ Product Moment $\left(r_{\text {theoritic }}\right)$ for the number of $\mathrm{N}$ is between 27-31 and the sig. value used is 5\% (Sugiyono, 2015)

The reliability of the instrument was calculated by the Alpha Cronbach coefficient as in Eq. (7) (Sugiyono, 2015).

$$
\mathrm{r}_{11}=\frac{\mathrm{k}}{\mathrm{k}-1}\left(1-\frac{\Sigma \sigma_{\mathrm{b}}^{2}}{\sigma_{\mathrm{t}}^{2}}\right)
$$

$r_{11}$ is the Alpha Cronbach reliability coefficient, $k$ is the number of questions and $\Sigma \sigma_{b}^{2}$ is the number of variants of each question. The variance value of each question calculated by Equation (8) while the total variance value calculated by Equation (9) (Sugiyono, 2015). 


$$
\begin{aligned}
\sigma_{\mathrm{b}}^{2} & =\frac{\Sigma \mathrm{X}_{\mathrm{i}}^{2}--\frac{\left(\Sigma \mathrm{X}_{\mathrm{i}}^{2}\right)}{\mathrm{n}}}{\mathrm{n}} \\
\sigma_{\mathrm{t}}^{2} & =\frac{\Sigma \mathrm{X}^{2}--\frac{\left(\Sigma \mathrm{X}^{2}\right)}{\mathrm{n}}}{\mathrm{n}}
\end{aligned}
$$

where $\sigma_{b}^{2}$ is the variance value of each question, $X_{i}$ is the student's answer for each question, $n$ is the number of students. $\sigma_{t}^{2}$ is the total variance value and $\Sigma X$ is the total student answer for each question.

The Alpha Cronbach reliability coefficient $\left(r_{11}\right)$ in Eq. (7) was compared with the Alpha Cronbach reliability coefficient criteria in Table 6 to determine whether the instrument is reliable or no. An instrument is reliable when the Alpha Cronbach reliability coefficient $\left(r_{11}\right)$ exceeds the $r_{\text {theoritic }}\left(r_{11}>r_{\text {theoritic }}\right)$. Table 11 shows the reliability of the Draft 3 (FTDT) on the UCM concepts.
Table 15. The limited trial was carried out using the Final Draft of the developed instrument.

\section{RESULTS AND DISCUSSION}

\section{A. Instrument development}

Table 7 presents one of the 15 questions in the Final Draft of the FTDT on the UCM concepts developed in this work and ready to be tested. The 14 other questions are intentionally not included in this article, considering that at the same time the document is being submitted to the Direktorat Jenderal Kekayaan Intelektual (DJKI), Kementerian Hukum dan Hak Asasi Manusia Republik Indonesia for the copy right.

Table 7. One of the 15 questions written in the Final Draft of the FTDT on UCM concepts
Table 6. Criteria for the reliability index using Alpha Cronbach (Arikunto,

\begin{tabular}{|c|c|c|}
\hline No & Reliability Index (r) & Criteria \\
\hline 1 & $0.800-1.000$ & Very High \\
\hline 2 & 0.600-0.799 & High \\
\hline 3 & $0.400-0.599$ & Medium \\
\hline 4 & $0.200-0.399$ & Low \\
\hline 5 & $-1.000-0.199$ & Very Low \\
\hline
\end{tabular}
2016)

\section{The limited trials}

The limited trial was conducted on 10 students at one of public high schools in Sidoarjo who had already taught the UCM concepts at the previous semester. The results that were analyzed using Table 2 are shown in

\section{Tier Question and Multi-tier test}

\section{Ordinary multiple-choice test}

Look at the Ferris Wheel in Figure 2 below!

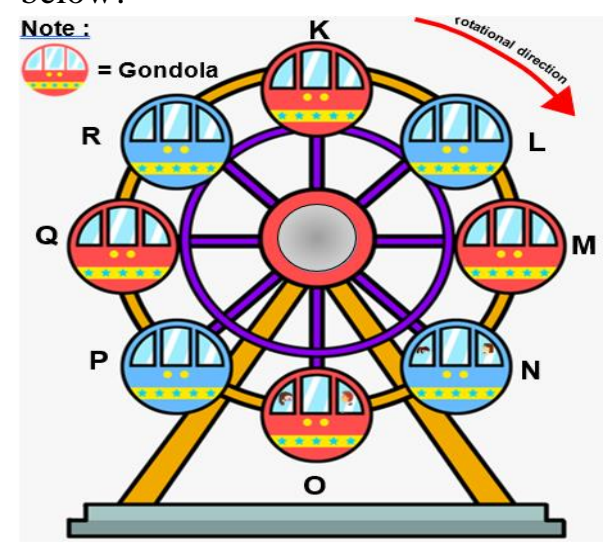

Figure 2. Ferris Wheel (Source: https://www.netclipart.com/isee/hTbR J_free-to-use-public-domain-ferriswheel-clip/) 
Figure 2 illustrates a Ferris wheel in an amusement park. The radius of the wheel is 18 meters and it has 8 gondolas, namely the $\mathrm{K}, \mathrm{L}, \mathrm{M}, \mathrm{N}, \mathrm{O}$, $\mathrm{P}, \mathrm{Q}$ and $\mathrm{R}$ gondolas. Each gondola can accommodate 2 visitors. Visitors can ride it by sitting in the available gondola. When the Ferris wheel is moving at a constant speed and makes one complete revolution in 12 minutes, the correct statement below about the direction of centripetal acceleration for each gondola is. . .

A. The direction of centripetal acceleration of the $\mathrm{K}$ gondola is upward, while the $\mathrm{O}$ gondola is downward

B. The direction of centripetal acceleration of the $\mathrm{M}$ gondola is to the right, while the $\mathrm{Q}$ gondola is to the left

C. The direction of centripetal acceleration for all gondola is toward the center of the ferris wheel

D. The direction of centripetal acceleration for all gondola is always outward away from the circular path

E. The direction of centripetal acceleration for all gondola in the ferris wheel is always tangent to the circle depends on the gondola position

\begin{tabular}{cl}
\hline $\mathbf{2}^{\text {nd }}$ & $\begin{array}{l}\text { Students' confidence level for } \\
\text { chosen answer }\end{array}$ \\
Tier & Are you sure about your answer? \\
& 1. Sure \\
2. Not sure
\end{tabular}

\section{Reasoning for the answer in the first} tier

Reason for the answer:

$3^{\text {rd }}$

A. The direction of centripetal

Tier

\section{(Preconception)}

B. The Ferris Wheel is moving at a constant velocity (Associative Thinking)

C. The direction of centripetal acceleration is the same as the direction of the ferris wheel's rotation (Humanistic Thinking)

D. The direction of centripetal acceleration is outward away from the circular path (Incomplete Reasoning)

E. The direction of centripetal acceleration is always perpendicular to the direction of linear velocity

F. The direction of centripetal acceleration is always parallel to the direction of linear velocity (Wrong Intuition)

$\begin{array}{cl}\mathbf{4}^{\text {th }} & \begin{array}{l}\text { Students' confidence level for } \\ \text { chosen reason }\end{array} \\ \text { Tier } & \begin{array}{l}\text { Are you sure about your reason? } \\ \text { 1. Sure }\end{array} \\ & \text { 2. Not sure }\end{array}$

\section{Drawing or making conclusion}

Draw the direction of the centripetal acceleration for each gondola in the Ferris wheel based on Figure 2!

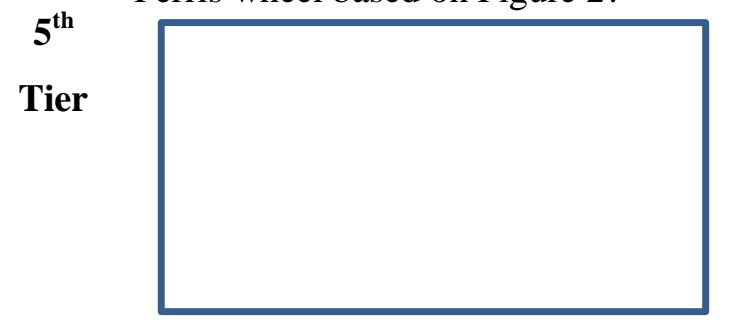

The first-tier on the question in Table 7 is a multiple-choice question that consists of one answer key (in bold) and other four answer options. The second-tier is the students' level of confidence in choosing the answer in the first-tier. The third-tier is the reason options for the chosen answer in the 
first-tier. This consists of one correct reason (in bold) and the other five reasons options.

The five reason options (italicized) were designed based on the misconceptions causes arising from the students, i.e. preconception, associative thinking, humanistic thinking, incomplete reasoning and wrong intuition (Saputri and Nurussaniah, 2015; Agustin et al., 2018; Fauziah and Darvina, 2019). The fourth-tier question contains the students' level of confidence when choosing the reason in the third-tier. The fifth-tier is an openedquestion, i.e. an instruction for students either to draw a sketch/picture/concept map or to write up a conclusion on the concept asked in the first-tier.

\section{B. Validity and reliability}

Table 8. The internal validity of the draft 2

\begin{tabular}{|c|c|c|c|c|c|c|c|}
\hline \multirow{2}{*}{ 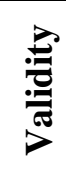 } & \multirow{2}{*}{$\begin{array}{l}\frac{n}{8} \\
\frac{0}{2} \\
\frac{2}{4}\end{array}$} & \multirow{2}{*}{ 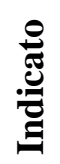 } & \multirow[b]{2}{*}{$=$} & \multicolumn{2}{|c|}{ Validator } & \multirow[b]{2}{*}{$\% \mathbf{P}$} & \multirow[b]{2}{*}{ Criteria } \\
\hline & & & & 1 & 2 & & \\
\hline \multirow{4}{*}{ 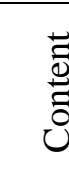 } & & $\mathrm{a}$ & & 4 & 4 & \multirow{4}{*}{94} & \multirow{2}{*}{ Very } \\
\hline & & $b$ & & 3 & 4 & & \\
\hline & & $\mathrm{c}$ & & 4 & 4 & & Valid \\
\hline & & d & & 3 & 4 & & \\
\hline \multirow{6}{*}{\multicolumn{2}{|c|}{ 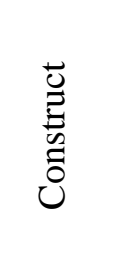 }} & $\mathrm{a}$ & & 3 & 4 & \multirow{6}{*}{92} & \multirow{6}{*}{$\begin{array}{l}\text { Very } \\
\text { Valid }\end{array}$} \\
\hline & & $b$ & & 4 & 4 & & \\
\hline & & $\mathrm{c}$ & & 3 & 4 & & \\
\hline & & d & & 3 & 4 & & \\
\hline & & $\mathrm{e}$ & & 3 & 4 & & \\
\hline & & $\mathrm{f}$ & & 4 & 4 & & \\
\hline \multirow{3}{*}{ 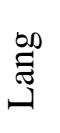 } & \multirow{3}{*}{$\begin{array}{l}\stackrel{\Xi}{0} \\
\stackrel{\Xi}{\Xi}\end{array}$} & $\mathrm{a}$ & & 3 & 3 & \multirow{3}{*}{79} & \multirow{3}{*}{ Valid } \\
\hline & & $\mathrm{b}$ & & 3 & 3 & & \\
\hline & & $\mathrm{c}$ & & 3 & 4 & & \\
\hline \multicolumn{6}{|c|}{ Average } & 88 & $\begin{array}{l}\text { Very } \\
\text { Valid }\end{array}$ \\
\hline
\end{tabular}

As seen in Table 8 , the average $\%$ of internal validity is $88 \%$ which is very valid (see Table 5).
Table 9. The external validity of the content aspect $(F P$ and $F N)$ of the draf 3 .

\begin{tabular}{|c|c|c|}
\hline $\begin{array}{l}\text { Question } \\
\text { Number }\end{array}$ & $\begin{array}{l}\text { False Positive } \\
\text { (FP) }\end{array}$ & $\begin{array}{c}\text { False } \\
\text { Negative }(\mathbf{F N})\end{array}$ \\
\hline 1 & 2 & 0 \\
\hline 2 & 0 & 0 \\
\hline 3 & 2 & 6 \\
\hline 4 & 1 & 2 \\
\hline 5 & 6 & 1 \\
\hline 6 & 3 & 1 \\
\hline 7 & 0 & 1 \\
\hline 8 & 2 & 3 \\
\hline 9 & 0 & 5 \\
\hline 10 & 1 & 2 \\
\hline 11 & 1 & 0 \\
\hline 12 & 3 & 0 \\
\hline 13 & 0 & 1 \\
\hline 14 & 2 & 2 \\
\hline 15 & 0 & 2 \\
\hline Total & 23 & 26 \\
\hline$\Sigma_{\text {students }}$ & \multicolumn{2}{|c|}{31} \\
\hline $\begin{array}{l}\Sigma_{\text {question }} \\
\times \Sigma_{\text {students }}\end{array}$ & \multicolumn{2}{|c|}{465} \\
\hline $\begin{array}{c}\text { Percentage } \\
(\%)\end{array}$ & 4,95 & 5,59 \\
\hline
\end{tabular}

Table 10. The construct aspect of external validity for each question in draft 3

\begin{tabular}{|c|c|c|c|}
\hline $\begin{array}{l}\text { Question } \\
\text { Number }\end{array}$ & $\begin{array}{c}\text { Correlation } \\
\text { Coefficient } \\
\left(r_{x y}\right)\end{array}$ & $\underset{\tilde{\Xi}}{\tilde{\Xi}}$ & Criteria \\
\hline 1 & 0,376 & \multirow{15}{*}{$\begin{array}{l}n \\
n \\
0 \\
0\end{array}$} & Valid \\
\hline 2 & 0,571 & & Valid \\
\hline 3 & 0,592 & & Valid \\
\hline 4 & 0,597 & & Valid \\
\hline 5 & 0,710 & & Valid \\
\hline 6 & 0,488 & & Valid \\
\hline 7 & 0,686 & & Valid \\
\hline 8 & 0,519 & & Valid \\
\hline 9 & 0,575 & & Valid \\
\hline 10 & 0,616 & & Valid \\
\hline 11 & 0,731 & & Valid \\
\hline 12 & 0,808 & & Valid \\
\hline 13 & 0,592 & & Valid \\
\hline 14 & 0,683 & & Valid \\
\hline 15 & 0,759 & & Valid \\
\hline $\begin{array}{c}r_{x y} \text { as a } \\
\text { whole }\end{array}$ & 0,998 & & Valid \\
\hline
\end{tabular}


Based on Table 9, it can be understood that from the 31 students tested, there are 4.95\% FP and $5.59 \% F N$ which meets the criteria $(<10 \%)$. Based on Table 10 , all of the correlation coefficient $\left(r_{x y}\right)$ for each question and the correlation coefficient as a whole $\left(r_{x y}=0,998\right)$ exceeds the $r_{\text {theoritic }}$. Based on the results in Tables 9 and 10, the Draft 3 is therefore valid and reliable.

Table 11. The reliability result of the Draft 3

\begin{tabular}{cccc}
\hline No & $\begin{array}{c}\text { Alpha } \\
\text { Cronbach } \\
\text { Reliability } \\
\text { Coefficient } \\
\left(\boldsymbol{r}_{\mathbf{1 1}}\right)\end{array}$ & $\boldsymbol{r}_{\text {theoritic }}$ & Criteria \\
& 0,887 & 0,355 & $\begin{array}{c}\text { Very } \\
\text { High }\end{array}$ \\
\hline 1 & & & \\
\hline
\end{tabular}

Based on Table 11, the reliability of the instrument is very high, i.e. $r_{11}=0,887$. This value far exceeds the $r_{\text {theoritic. Therefore, }}$ according to the criteria for a valid instrument given by (Riduwan \& Akdon, 2013); (Jannah \& Ermawati, 2020); (Arikunto, 2016); and according to the reliability criteria of an instrument according to (Sugiyono, 2015), the Draft 3 (FTDT) developed in this work is valid and reliable.

\section{The limited trials result}

Table 12-14 shows the answers of the Student No. 1-3 of the total 10 students and their conception levels evaluated by the author. Table 15 recapitulates the 10 students' conception levels.
Table 12. Student No. 1 answers

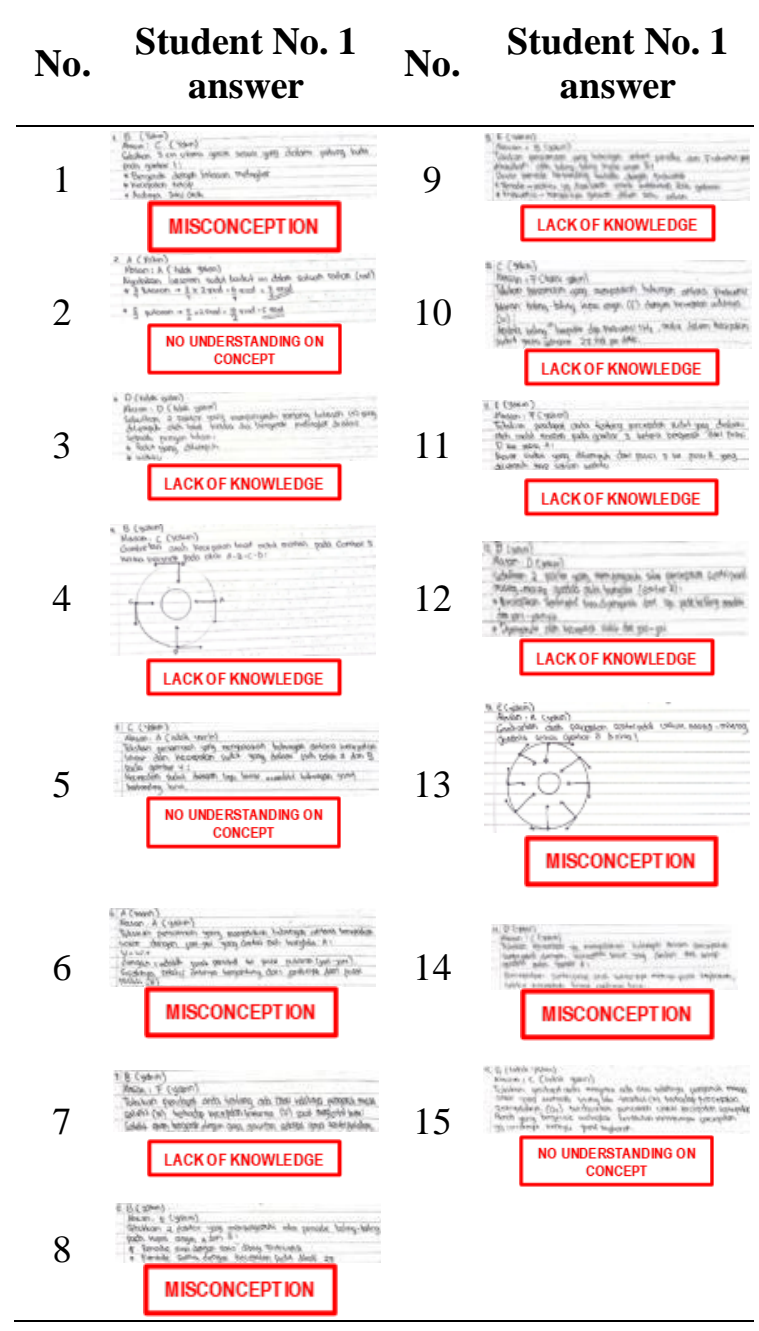


Table 13. Student No. 2 answers

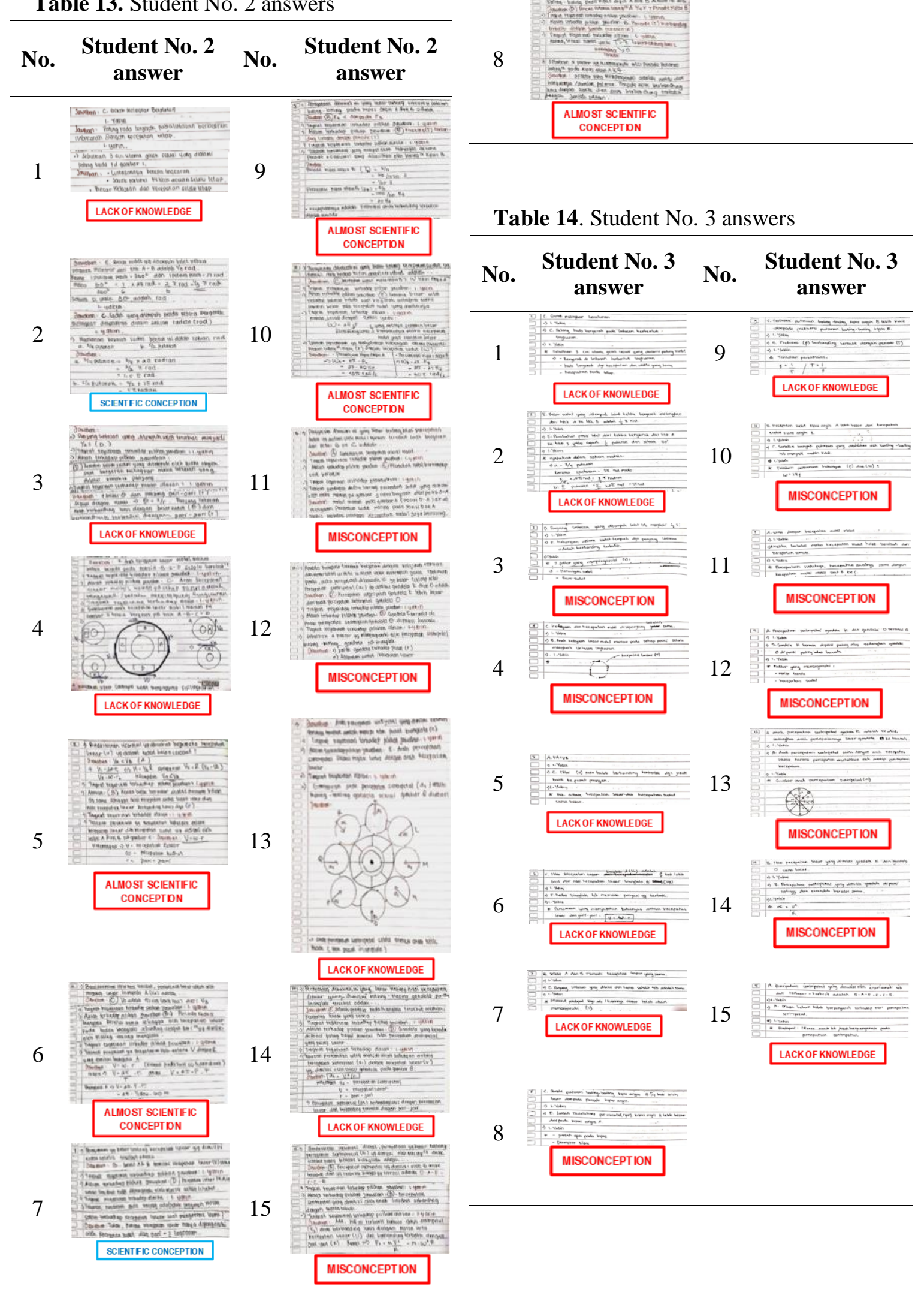


Table 15. The conception levels of the 10 students examined using the final draft of FTDT

\begin{tabular}{|c|c|c|c|c|c|c|c|c|c|c|c|}
\hline \multirow{2}{*}{ 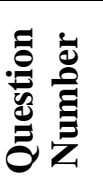 } & \multirow{2}{*}{ 离 } & \multicolumn{10}{|c|}{ Students' conception level (-th)* } \\
\hline & & 1 & 2 & 3 & 4 & 5 & 6 & 7 & 8 & 9 & 10 \\
\hline 1 & $\mathrm{a}$ & $\begin{array}{c}\text { MS( } \\
\text { A) }\end{array}$ & LK & LK & LK & $\begin{array}{l}\text { MSC } \\
\text { (I) }\end{array}$ & $\begin{array}{l}\text { MSC } \\
\text { (I) }\end{array}$ & LK & ASC & ASC & LK \\
\hline 2 & $\mathrm{~b}$ & NU & $\mathrm{SC}$ & LK & $\mathrm{SC}$ & LK & NU & LK & LK & NU & LK \\
\hline 3 & $\mathrm{c}$ & LK & LK & $\begin{array}{l}\text { MSC } \\
\text { (I) }\end{array}$ & NU & LK & LK & $\begin{array}{c}\text { MSC } \\
\text { (I) }\end{array}$ & $\begin{array}{c}\text { MSC } \\
\text { (I) }\end{array}$ & LK & $\begin{array}{c}\text { MSC } \\
\text { (I) }\end{array}$ \\
\hline 4 & $\mathrm{~d}$ & LK & LK & $\begin{array}{c}\text { MSC } \\
\text { (A) }\end{array}$ & $\begin{array}{l}\text { MSC } \\
\text { (I) }\end{array}$ & $\begin{array}{l}\text { MSC } \\
\text { (A) }\end{array}$ & $\begin{array}{l}\text { MSC } \\
\text { (I) }\end{array}$ & $\begin{array}{l}\text { MSC } \\
\text { (A) }\end{array}$ & $\begin{array}{c}\text { MSC } \\
\text { (I) }\end{array}$ & $\begin{array}{c}\text { MSC } \\
(\mathrm{P})\end{array}$ & $\begin{array}{c}\text { MSC } \\
\text { (A) }\end{array}$ \\
\hline 5 & $\mathrm{e}$ & NU & ASC & LK & LK & LK & LK & LK & $\begin{array}{c}\text { MSC } \\
\text { (I) }\end{array}$ & LK & LK \\
\hline 6 & $\mathrm{f}$ & $\begin{array}{c}\text { MSC } \\
(\mathrm{P})\end{array}$ & ASC & LK & LK & NU & $\mathrm{NU}$ & LK & LK & LK & LK \\
\hline 7 & $\mathrm{~g}$ & LK & $\mathrm{SC}$ & LK & $\begin{array}{c}\text { MSC } \\
(\mathrm{H})\end{array}$ & LK & $\mathrm{SC}$ & LK & LK & LK & LK \\
\hline 8 & $\mathrm{~h}$ & $\begin{array}{c}\text { MSC } \\
(\mathrm{R})\end{array}$ & ASC & $\begin{array}{c}\text { MSC } \\
(\mathrm{R})\end{array}$ & LK & LK & NU & NU & $\begin{array}{c}\text { MSC } \\
(\mathrm{R})\end{array}$ & LK & $\begin{array}{c}\text { MSC } \\
\text { (R) }\end{array}$ \\
\hline 9 & $\mathrm{i}$ & LK & ASC & LK & ASC & LK & LK & LK & LK & LK & LK \\
\hline 10 & $\mathrm{j}$ & LK & ASC & $\begin{array}{c}\text { MSC } \\
(\mathrm{H})\end{array}$ & $\begin{array}{c}\text { MSC } \\
(\mathrm{H})\end{array}$ & NU & LK & $\begin{array}{c}\text { MSC } \\
(\mathrm{H})\end{array}$ & LK & LK & $\begin{array}{c}\text { MSC } \\
(\mathrm{H})\end{array}$ \\
\hline 11 & $\mathrm{k}$ & LK & $\begin{array}{c}\text { MSC } \\
(\mathrm{H})\end{array}$ & $\begin{array}{c}\text { MSC } \\
(\mathrm{P})\end{array}$ & LK & $\begin{array}{c}\text { MSC } \\
(\mathrm{P})\end{array}$ & $\mathrm{NU}$ & NU & LK & $\begin{array}{c}\text { MSC } \\
(\mathrm{P})\end{array}$ & $\begin{array}{c}\text { MSC } \\
\text { (P) }\end{array}$ \\
\hline 12 & 1 & LK & $\begin{array}{c}\text { MSC } \\
(\mathrm{H})\end{array}$ & $\begin{array}{c}\text { MSC } \\
(\mathrm{H})\end{array}$ & LK & $\begin{array}{l}\text { MSC } \\
\text { (I) }\end{array}$ & NU & $\begin{array}{c}\text { MSC } \\
(\mathrm{H})\end{array}$ & ASC & $\mathrm{NU}$ & $\begin{array}{c}\text { MSC } \\
(\mathrm{H})\end{array}$ \\
\hline 13 & $\mathrm{~m}$ & $\begin{array}{c}\text { MSC } \\
(\mathrm{P})\end{array}$ & LK & $\begin{array}{c}\text { MSC } \\
(\mathrm{P})\end{array}$ & $\mathrm{SC}$ & LK & ASC & $\begin{array}{c}\text { MSC } \\
(\mathrm{P})\end{array}$ & ASC & LK & $\begin{array}{c}\text { MSC } \\
\text { (P) }\end{array}$ \\
\hline 14 & $\mathrm{n}$ & $\begin{array}{c}\text { MSC } \\
\text { (A) }\end{array}$ & LK & $\begin{array}{c}\text { MSC } \\
(\mathrm{P})\end{array}$ & LK & $\begin{array}{c}\text { MSC } \\
(\mathrm{P})\end{array}$ & $\mathrm{NU}$ & $\begin{array}{c}\text { MSC } \\
(\mathrm{P})\end{array}$ & LK & LK & $\begin{array}{c}\text { MSC } \\
\text { (P) }\end{array}$ \\
\hline 15 & o & $\mathrm{NU}$ & $\begin{array}{c}\text { MSC } \\
(\mathrm{P})\end{array}$ & LK & $\mathrm{SC}$ & LK & $\begin{array}{c}\text { MSC } \\
(\mathrm{H})\end{array}$ & LK & SC & LK & LK \\
\hline
\end{tabular}

\section{Note:}

*Based on the $7^{\text {th }}$ column in Table 2

Sub-concept: $\mathrm{a}=\mathrm{UCM}$ characteristics, $\mathrm{b}=$ angular displacement, $\mathrm{c}=$ the relationship between angular displacement and the length of the path, $\mathrm{d}=$ linear velocity, $\mathrm{e}=$ the relationship between linear velocity and angular velocity, $\mathrm{f}=$ the relationship between the linear velocity and the radius of the path, $\mathrm{g}=$ the effect of object's mass on the linear velocity, $\mathrm{h}=$ period, $\mathrm{i}=$ frequency, $\mathrm{j}=$ relationship between frequency and angular velocity, $\mathrm{k}=$ angular acceleration, 1 $=$ value of centripetal acceleration, $\mathrm{m}=$ direction of centripetal acceleration, $\mathrm{n}=$ relationship between centripetal acceleration and linear velocity, $o=$ effect of object's mass on centripetal acceleration.

MSC $(\mathrm{P})=$ preconception, MSC $(\mathrm{H})=$ humanistic thinking, MSC $(\mathrm{A})=$ associative thinking,

MSC $(\mathrm{R})=$ incomplete reasoning, $\mathrm{MSC}$ (I) $=$ wrong intuition. 
Based on Table 15, the student No. 1 is lack of knowledge on 7 sub-concepts (Question No. 2-3, 7 and 9-12). The student No. 2 is lack of knowledge on 5 sub concepts (Question No. 1, 3-4 and 13-14). The student No. 3 experienced misconceptions on 8 subconcepts (Question No. 3-4, 8 and 10-14), which is dominantly caused by preconception. For example, for the question No. 13, he was identified experienced misconception due to preconceptions. $\mathrm{He}$ assumed that the direction of centripetal acceleration is the same as the direction of linear velocity because acceleration was caused by a change in velocity. Meanwhile, according to the Physics concept, the direction of centripetal acceleration is always perpendicular to the direction of linear velocity.

The student No. 4 is lack of knowledge on 7 sub-concepts (Question No. 1, 5-6, 8, 11-12 and 14). The student No. 5 is lack of knowledge on 8 sub-concepts (Question No. 2-3, 5, 7-9, 13 and 15). The student No. 6 experienced no understanding on a concept on 6 sub-concepts (Question No. 2, 6, 8, 11-12 and 14). The student No. 7 is lack of knowledge on 7 sub-concepts (Question No. 1-2, 5-7, 9 and 15). The student No. 8 is lack of knowledge on 7 sub-concepts (Question No. 2, 6-7, 9-11 and 14). The student No. 9 is lack of knowledge on 10 sub-concepts (Question No. 3, 5-10 and 13-15). The student No. 10 experienced misconception on 8 sub-concept (Question No. 3-4, 8 and 10-
14). Based on the result above, in general it can be concluded that $46.0 \%$ of the students experienced lack of knowledge, $31.33 \%$ had misconception, $10.67 \%$ students had no understanding on the concepts; $7.33 \%$ students are almost scientific conception and only $4.67 \%$ of the students understood the concepts (scientific conception).

\section{CONCLUSION AND SUGGESTION}

\section{A. Conclusion}

The development of a FTDT with 15 question on the UCM concepts has been completed. The instrument is valid and reliable. The limited test given to 10 students shows that the instrument successfully identified the conception levels for each student on the UCM concepts, i.e. almost $50 \%$ of the students suffered lack of knowledge.

\section{B. Suggestion}

The FTDT on the UCM concepts can be used to test the conception levels of students from other schools. By doing so, the teacher has the data on the students' learning difficulties and can find appropriate treatments to solve it.

\section{REFERENCES}

Agustin, R. D., Harijanto, A., \& Prastowo, S. H. B. (2018). Identifikasi miskonsepsi siswa pada materi rangkaian arus bolakbalik menggunakan four-tier test di SMA. Jurnal Pembelajaran Fisika, 7 (2), 141-146. 
Alhinduan, S. R., Kurniawan, Y., \& Mulyani, R. (2016). Identifikasi kuantitas siswa yang miskonsepsi menggunakan three tier-test pada materi listrik dinamis. Jurnal Ilmu Pendidikan Fisika (JIPF), 1 (1), 29-31.

https://journal.stkipsingkawang.ac.id/index.php/J IPF/article/view/57/35

Amin, N., Wiendartun, W., \& Samsudin, A. (2016). Analisis intrumen tes diagnostik dynamic-fluid conceptual change inventory (DFCCI) bentuk four-tier test pada beberapa SMA di Bandung Raya. Prosiding Simposium Nasional Inovasi dan Pembelajaran Sains (SNIPS) 2016 (pp 570-574). Bandung, Indonesia.

Anam, R. S., Widodo, A., Sopandi, W., \& Wu, H. K. (2019). Developing a five-tier diagnostic test to identify students' misconceptions in science: an example of the heat transfer concepts. Elementary Education Online, 18 (03), 1014-1029.

Annisa, Rizki, Astuti. B., \& Mindyarto, B. N., (2019). Tes diagnostik four tier untuk identifikasi pemahaman dan miskonsepsi siswa pada materi gerak melingkar beraturan. Jurnal Pendidikan Fisika dan Keilmuan (JPFK), 5 (1), 25-32. https://core.ac.uk/download/pdf/2294937 $15 . p d f$

Arikunto, S. (2016). Dasar-dasar evaluasi pendidikan edisi 2. Jakarta: PT. Bumi Aksara.

Astuti, S. P., (2015). Pengaruh kemampuan awal dan minat belajar terhadap prestasi belajar fisika. Formatif: Jurnal Ilmiah Pendidikan MIPA, 5 (1), 68-75.

https://journal.lppmunindra.ac.id/index.p hp/Formatif/article/view/167/160

Bayuni, T. C., Sopandi, W., \& Sujana, A. (2018). Identification misconception of primary school teacher education students in changes of matters using a five-tier diagnostic test. Journal of Physics: Conference Series, 1013 (1), 012086.

https://iopscience.iop.org/article/10.1088 11742-6596/1013/1/012086/pdf

Dikmenli, M. (2010). Misconceptions of cell division held by student teachers in biology: a drawing analysis. Scientific Research and Essay, 05 (02), 235- 247.
https://academicjournals.org/journal/SRE /article-full-text-pdf/E98624416980

Ermawati, F. U., Anggrayni, S., \& Isfara, L. (2019). Misconception profile of students in senior high school IV Sidoarjo East Java in work and energy concepts and the causes evaluated using four-tier diagnostic test. Journal of Physics: Conference Series, 1387 (1), 012062.

https://iopscience.iop.org/article/10.1088 /1742-6596/1387/1/012062/pdf.

Fajriyyah, N. S., \& Ermawati, F. U. (2020). The validity and reliability of five-tier conception diagnostic test for kinetic theory of gases. Jurnal Inovasi Pendidikan Fisika, 9 (2), 126-132. https://jurnalmahasiswa.unesa.ac.id/inde x.php/inovasi-pendidikanfisika/article/view/33889/30369.

Farihah, U., \& Wildani, A. (2018). Identifikasi miskonsepsi siswa dengan three tier essay test item pada materi hukum newton di SMA Negeri 1 Pademawu. Wacana Didaktika, 6 (01), 86-100.

http://journal.uim.ac.id/index.php/wacan adidaktika/article/view/460/402

Fauziah, A., \& Darvina, Y. (2019). Analisis miskonsepsi peserta didik dalam memahami materi gerak lurus dan gerak parabola pada kelas X SMAN 1 Padang. Pillar of Physics Education, 12 (1), 7380.

Fitriani, N., Gunawan, G., \& Sutrio, S. (2017). Berpikir kreatif dalam fisika dengan pembelajaran conceptual understanding procedures (CUPs) berbantuan LKPD. Jurnal Pendidikan Fisika dan Teknologi, 3 (1), 24-33. http://www.jurnalfkip.unram.ac.id/index. php/JPFT/article/view/319/310

Giancoli, D. C. (2014). Physics: principles with applications 7 th edition. Boston: Pearson.

Gurel, D. K., Eryilmaz, A., \& McDermott, L. C. (2015). A Review and comparison of diagnostic instruments to identify students' misconceptions in science. Eurasia Journal of Mathematics, Science and Technology Education, 11 (5), 989-1008. 
https://open.metu.edu.tr/bitstream/hand le/11511/38957/index.pdf.

Halliday, D., Resnick, R., \& Walker, J. (2013). Fundamentals of physics 10th edition. Hoboken, New Jersey: John Wiley \& Sons Inc.

Haryono, H. E., Aini, K. N., Samsudin, A., \& Siahaan, P. (2020). The implementation of cognitive conflict learning strategy in efforts to reduce heat misconception in junior high school students. Jurnal Pendidikan Fisika, 8 (3), 319-327.

https://jurnal.unismuh.ac.id/index.php/jpf /article/view/3950/2765

Ilyas, I., Liu, A. N. A. M., \& Doa, H. (2020). The influence of virtual labs on the students' learning outcomes and scientific attitudes at physics education study program flores university. Jurnal Pendidikan Fisika, 8 (1), 23-32.

https://jurnal.unismuh.ac.id/index.php/jpf /article/view/2831/2391

Jannah, E. M., \& Ermawati, F. U. (2020). Identify 11th grade of senior high school Jogoroto students' misconceptions on dynamic rotation and rigid body equilibrium concepts using four-tier diagnostic test. Journal of Physics: Conference Series, 1491 (1), 012010. https://iopscience.iop.org/article/10.1088 /1742-6596/1491/1/012010/pdf.

Kemendikbud. (2014). Konsep dan implementasi kurikulum 2013. Jakarta, Indonesia: Departemen Pendidikan dan Kebudayaan.

Kirbulut, Z. D., \& Geban, O. (2014). Using three-tier diagnostic test to assess students' misconceptions of states of matter. Eurasia Journal of Mathematics, Science and Technology Education, 10 (5), 509-521.

https://www.ejmste.com/download/using -three-tier-diagnostic-test-to-assessstudents-misconceptions-of-states-ofmatter-4321.pdf.

Köse, S. (2008). Diagnosing student misconceptions: using drawings as a research method. World Applied Sciences Journal, 3 (2), 283-293. http://citeseerx.ist.psu.edu/viewdoc/dow nload?doi=10.1.1.388.382\&rep=rep1\&ty pe=pdf.
Milenković, D. D., Hrin, T. N., Segedinac, M. D., \& Horvat, S. (2016). Development of a three-tier test as a valid diagnostic tool for identification of misconceptions related to carbohydrates. Journal of Chemical Education, 93 (9), 1514-1520.

Pebriyanti, D., Sahidu, H., \& Sutrio, S. (2017). Efektifitas model pembelajaran perubahan konseptual untuk mengatasi miskonsepsi fisika pada siswa kelas $\mathrm{x}$ SMAN 1 Praya Barat tahun pelajaran 2012/2013. Jurnal Pendidikan Fisika dan Teknologi, 1 (2), 92-96. http://jurnalfkip.unram.ac.id/index.php/J PFT/article/view/241/237.

Qonita, M., \& Ermawati, F. U. (2020). The validity and reliability of five-tier conception diagnostic test for vector concepts. Jurnal Inovasi Pendidikan Fisika, 9 (03), 459-465. https://ejournal.unesa.ac.id/index.php/ino vasi-pendidikan-

fisika/article/view/35743.

Respatiningrum, N., Radiyono, Y., \& Wiyono, E. (2015). Analisis miskonsepsi materi fluida pada buku ajar fisika SMA. Prosiding Seminar Nasional Fisika dan Pendidikan Fisika (SNFPF) 2015 (pp. 313-317). Solo, Indonesia. https://core.ac.uk/download/pdf/2897907 61.pdf

Riduwan, \& Akdon. (Ed.). (2013). Rumus dan data dalam analisis statistika (edisi kelima). Bandung: ALFABETA.

Rukmana, A. P., Tantri M. and Andista C. Y. (2020). Pengembangan four-tier diagnostic test untuk mendeteksi miskonsepsi pada fisika SMA. Prosiding Seminar Nasional Pendidikan Fisika (SNPF) 2020 (pp. 1-6). Madiun, Indonesia.

Salsabila, F. N., \& Ermawati, F. U. (2020). Validity and reliability of conception diagnostic test using five-tier format for elasticity concepts. Jurnal Inovasi Pendidikan Fisika, 9 (03), 439-446. https://ejournal.unesa.ac.id/index.php/ino vasi-pendidikanfisika/article/view/35747.

Saputri, D. F., \& Nurussaniah, N. (2015). Penyebab miskonsepsi pada optika geometris. Prosiding Seminar Nasional 
Fisika (E-Journal) 2015 (pp. 33-36). Jakarta, Indonesia.

http://journal.unj.ac.id/unj/index.php/pro sidingsnf/article/view/5022/3708

Serway, R., Faughn, J., \& Vuille, C. (2010). College physics ninth edition. Boston: Cengage Learning.

Sholihat, F. N., Samsudin, A., \& Nugraha, M. G. (2017). Identifikasi miskonsepsi dan penyebab miskonsepsi siswa menggunakan four-tier diagnostic test pada sub-materi fluida dinamik: azas kontinuitas. Jurnal Penelitian \& Pengembangan Pendidikan Fisika, 3 (2), 175-180. http://journal.unj.ac.id/unj/index.php/jpp pf/article/view/4602/4005

Sugiyono. (2015). Metode penelitian pendidikan pendekatan kuantitatif, kualitatif dan $R \& D$. Bandung: ALFABETA.

Yolenta, Desfhie, \& Leo, S. (2014). Deskripsi miskonsepsi siswa SMA Sekecamatan Kapuas tentang gerak melingkar beraturan menggunakan three-tier test. Jurnal Pendidikan dan Pembelajaran Khatulistiwa, 4 (3), 1-7. https://jurnal.untan.ac.id/index.php/jpdpb /article/view/9310/9205. 